\title{
RESEARCH
}

Open Access

\section{R-cembranoid confers neuroprotection against LPS-induced hippocampal inflammation in mice}

Luis A. Rojas-Colón ${ }^{1}$, Pramod K. Dash, Fabiola A. Morales-Vías' ${ }^{1}$, Madeline Lebrón-Dávila ${ }^{1}$ Pedro A. Ferchmin ${ }^{1}$, John B. Redell², Geronimo Maldonado-Martínez ${ }^{3}$ and Wanda I. Vélez-Torres ${ }^{1 *}$

\begin{abstract}
Background: Chronic brain inflammation has been implicated in the pathogenesis of various neurodegenerative diseases and disorders. For example, overexpression of pro-inflammatory cytokines has been associated with impairments in hippocampal-dependent memory. Lipopolysaccharide (LPS) injection is a widely used model to explore the pathobiology of inflammation. LPS injection into mice causes systemic inflammation, neuronal damage, and poor memory outcomes if the inflammation is not controlled. Activation of the alpha-7 nicotinic receptor (a7) plays an anti-inflammatory role in the brain through vagal efferent nerve signaling. 4R-cembranoid (4R) is a natural compound that crosses the blood-brain barrier, induces neuronal survival, and has been shown to modulate the activity of nicotinic receptors. The purpose of this study is to determine whether $4 R$ reduces the deleterious effects of LPS-induced neuroinflammation and whether the a7 receptor plays a role in mediating these beneficial effects.
\end{abstract}

Methods: Ex vivo population spike recordings were performed in C57BL/6J wild-type (WT) and alpha-7-knockout (a7KO) mouse hippocampal slices in the presence of $4 \mathrm{R}$ and nicotinic receptor inhibitors. For in vivo studies, WT and a7KO mice were injected with LPS for $2 \mathrm{~h}$, followed by $4 \mathrm{R}$ or vehicle for $22 \mathrm{~h}$. Analyses of IL-1 $\beta$, TNF-a, STAT3, CREB, Akt1, and the long-term novel object recognition test (NORT) were performed for both genotypes. In addition, RNA sequencing and RT-qPCR analyses were carried out for 12 mRNAs related to neuroinflammation and their modification by $4 R$.

Results: 4R confers neuroprotection after NMDA-induced neurotoxicity in both WT and a7KO mice. Moreover, hippocampal TNF- $\alpha$ and IL-1 $\beta$ levels were decreased with 4R treatment following LPS exposure in both strains of mice. $4 R$ restored LPS-induced cognitive decline in NORT. There was a significant increase in the phosphorylation of STAT3, CREB, and Akt1 with 4R treatment in the WT mouse hippocampus following LPS exposure. In a7KO mice, only pAkt levels were significantly elevated in the cortex. 4R significantly upregulated mRNA levels of ORM2, GDNF, and C3 following LPS exposure. These proteins are known to play a role in modulating microglial activation, neuronal survival, and memory.

(Continued on next page)

\footnotetext{
* Correspondence: wanda.velez@uccaribe.edu

'Department of Biochemistry, Universidad Central del Caribe School of

Medicine, Av. Sta. Juanita, Bayamón 00960, Puerto Rico

Full list of author information is available at the end of the article
}

(c) The Author(s). 2021, corrected publication 2021. Open Access This article is licensed under a Creative Commons Attribution 4.0 International License, which permits use, sharing, adaptation, distribution and reproduction in any medium or format, as long as you give appropriate credit to the original author(s) and the source, provide a link to the Creative Commons licence, and indicate if changes were made. The images or other third party material in this article are included in the article's Creative Commons licence, unless indicated otherwise in a credit line to the material. If material is not included in the article's Creative Commons licence and your intended use is not permitted by statutory regulation or exceeds the permitted use, you will need to obtain permission directly from the copyright holder. To view a copy of this licence, visit http://creativecommons.org/ licenses/by/4.0/. The Creative Commons Public Domain Dedication waiver (http://creativecommons.org/publicdomain/zero/1. 0/) applies to the data made available in this article, unless otherwise stated in a credit line to the data. 
(Continued from previous page)

Conclusion: Our results indicate that 4R decreases the levels of pro-inflammatory cytokines; improves memory function; activates STAT3, Akt1, and CREB phosphorylation; and upregulates the mRNA levels of ORM2, GDNF, and C3. These effects are independent of the a7 nicotinic receptor.

Keywords: Neuroinflammation, Mice, 4R, TNF-a, IL-1ß, Akt1, CREB, a7 receptor

\section{Background}

Chronic neuroinflammation is a key feature of a number of neurological diseases and disorders, such as Alzheimer's disease [1], Parkinson's disease [2], ischemic stroke, depression [3], and traumatic brain injury [4]. Lipopolysaccharide (LPS), a bacterial endotoxin, has been widely used as an in vivo animal model for investigation into peripherally and centrally induced inflammation. LPS activates the TLR-4 intracellular signaling pathway, which regulates the nuclear translocation of NF- $\mathrm{kB}$ and the gene expression of pro-inflammatory cytokines [5-7]. Transfer of peripheral inflammation to the brain by intraperitoneal injection of LPS occurs through activation of vagal afferent nerves [8]. The brain's rapid anti-inflammatory action involves the vagal efferent acetylcholine release and activation of the $\alpha 7$ nicotinic acetylcholine receptors on periphery inflammatory cells. Peripheral pro-inflammatory cytokines can also bind to their respective receptors in the brain endothelium and induce NF- $\kappa \beta$ activation or can enter the brain through the blood-brain barrier-free circumventricular organs [9].

LPS increases the levels of plasma, hippocampal, and cortical pro-inflammatory cytokines [10-12] and impairs hippocampus-dependent learning and memory in mice $[13,14]$. The hippocampus contains glial cells, such as microglia and astrocytes, that maintain normal physiological functions [15]. Abnormal activation of astrocytes and microglia leads to the secretion of pro-inflammatory proteins that increase the neuroinflammatory response [16]. Modulating microglial phenotypes can lower neuroinflammation and increase tissue repair activity [17]. Astrocytes can secrete neurotrophic factors involved in decreasing microglial activation and promoting neuronal survival [18].

4R-cembranoid (4R) is a natural diterpenoid compound found in soft corals and tobacco plants and known for its antimicrobial and neuroprotective activities [19]. Ex vivo and in vivo studies have shown that $4 \mathrm{R}$ significantly protects neurons against NMDA-induced neurotoxicity [20] and organophosphate poisoning $[21,22]$. In a rat model of ischemic stroke, 4R administered $1 \mathrm{~h}$ after reperfusion resulted in a $60 \%$ reduction in the infarct size compared with vehicle [23]. Furthermore, $4 \mathrm{R}$ treatment significantly reverses the motor disabilities associated with Parkinson's disease in rats [24]. The $4 \mathrm{R}$ concentration in the brain is higher than in plasma when administered parenterally to rats [25].

Nicotine administration decreases pro-inflammatory cytokine release from specific brain regions, such as the striatum, hippocampus, and cerebral cortex, in rats receiving an intracerebroventricular injection of LPS. This effect was reversed by antagonists of the $\alpha 7$ receptor but not by antagonists of the $\alpha 4 \beta 2$ receptor [26]. In a traumatic brain injury model, $\alpha 7$-knockout $(\alpha 7 \mathrm{KO})$ mice had significantly higher plasma levels of TNF- $\alpha$ and IL-1 $\beta$ than WT mice [27]. Furthermore, previous studies have shown that $4 R$ is an antagonist of neuronal acetylcholine receptors. Incubation with $4 \mathrm{R}$ inhibited carbamoylcholine-induced currents in cells expressing human $\alpha 4 \beta 2$ and $\alpha 3 \beta 4$ in a noncompetitive manner [28]. 4R also inhibited acetylcholineevoked currents in cells transfected with human $\alpha 7$ nicotinic acetylcholine receptors [29].

The present study examines the neuroprotective effect of $4 \mathrm{R}$ during LPS-induced brain inflammation. It also considers the role of the $\alpha 7$ receptors in this effect and explores possible mechanisms of action of $4 \mathrm{R}$.

\section{Methods \\ Materials}

The cembranoid 4R was prepared by Dr. K. El Sayed (School of Pharmacy, University of Louisiana, Monroe, LA) as previously described [30]. The purity of the batch used for these experiments was more than $98 \%$. The $4 R$ solvent consisted of $99.6 \%$ polyethylene glycol (PEG) and $0.4 \%$ dimethyl sulfoxide (DMSO). LPS from Escherichia coli serotype 026:B6 was purchased from Sigma-Aldrich (St. Louis, MO) and freshly dissolved in sterile saline $(0.9 \% \mathrm{NaCl})$. N-Methyl-D-aspartic acid (NMDA) and dihydro- $\beta$-erythroidine (DH $\beta E$ ) were purchased from Sigma-Aldrich. Methyllycaconitine (MLA) was purchased from Calbiochem (La Jolla, CA).

\section{Animals}

Three C57BL/6J $\alpha 7$-knockout and three heterozygous breeding pairs were obtained from Jackson Laboratories (Stock \# 003232, Bar Harbor, ME) and bred in the Universidad Central del Caribe animal facility in a temperature-controlled room with free access to food and water and under a 12-hour light/dark cycle. The 
$\alpha 7 \mathrm{KO}$ mice were genotyped by PCR using the primers recommended by Jackson Laboratories in order to select the null $(-/-)$ and WT mice for experiments. All mice used were males and females 8-10 weeks of age. The Institutional Animal Care and Use Committee at UCC approved all mouse protocols.

\section{Hippocampal slice recordings}

Mouse brains were removed, and the hippocampus dissected on ice and perfused with cold artificial cerebrospinal fluid (ACSF) saturated with $95 \% \mathrm{O}_{2}$ and $5 \% \mathrm{CO}_{2}$ [20]. The composition of the ACSF (in $\mathrm{mM}$ ) was 125 $\mathrm{NaCl}, 3.3 \mathrm{KCL}, 1.25 \mathrm{NaH}_{2} \mathrm{PO}_{4}, 2 \mathrm{MgSO}_{4}, 2 \mathrm{CaCl}_{2}, 25$ $\mathrm{NaHCO}_{3}$, and 10 glucose. Transverse slices $(400 \mu \mathrm{m}$ thick) were obtained using a manual slicer. The hippocampal slices were transferred in equal amounts to a three-lane recording chamber, each with a perfusion line exposed to ACSF, $95 \% \mathrm{O}_{2}$, and $5 \% \mathrm{CO}_{2}$ at $34.5^{\circ} \mathrm{C}$. A maximum of seven hippocampal slices was analyzed per lane per experimental condition. An electrode was placed in the stratum radiatum of the CA1 area to stimulate the Shaffer collaterals, and another electrode was placed in the stratum pyramidale to record the stimulus-evoked population spike (PS). The strength of the stimulus used was twice the strength required to elicit a threshold response. The PS was analyzed using the LABMAN program (gift from Dr. T.J. Teyler to Dr. PA Ferchmin, WWAMI Medical Education Program, University of Idaho, Moscow, ID). The percent PS area (msec $\mathrm{x} \mathrm{mV}$ ) was obtained by dividing the PS during treatment with the PS during perfusion with ACSF only. The loss or recovery of the PS area was used as an indicator of neurotoxicity or neuroprotection, respectively.

The first experimental condition was the control treatment followed by the effect of $4 \mathrm{R}$ before and after NMDA toxicity. The NMDA concentration and time were set to allow a 20\% PS recovery in those slices treated with NMDA only. NMDA was removed by washing the slices with ACSF for $30 \mathrm{~min}$. These three experimental conditions were carried out in hippocampal slices from WT and $\alpha 7 \mathrm{KO}$ mice. Two more experimental conditions included the presence of two inhibitors, DH $\beta E$ and MLA, at concentrations selective for the $\alpha 4$ and $\alpha 7$ subunitcontaining nicotinic acetylcholine receptors, respectively. At the end of the experimental treatments and after $1 \mathrm{~h}$ recovery with ACSF, the final PS was recorded using the same stimulus strength and position as the initial PS.

\section{Sample collection}

Mice were randomly divided into five groups: 1) saline, 2) $4 \mathrm{R}, 3) \mathrm{LPS} /$ saline, 4) LPS/vehicle, and 5) LPS/4R. Mice were injected intraperitoneally (i.p.) with saline $(0.9 \% \mathrm{NaCl})$ or LPS $(5 \mathrm{mg} / \mathrm{kg})$. $4 \mathrm{R}(6 \mathrm{mg} / \mathrm{kg})$ or vehicle (99.6\% PEG/0.4\% DMSO) was injected subcutaneously (s.c.). In groups 3, 4 and 5, mice received LPS for 2 hours and at the end of 2 hours were injected with either saline, vehicle or $4 \mathrm{R}$. All mice were sacrificed $24 \mathrm{~h}$ post first injection. Blood was collected by retro-orbital bleeding using capillary tubes containing heparin as an anticoagulant (VWR; cat. \# 15401-560). Samples were centrifuged at $10,000 \times g$ at $4{ }^{\circ} \mathrm{C}$ for $10 \mathrm{~min}$ and plasma collected and stored at $-80^{\circ} \mathrm{C}$ until further analysis. Brains were removed and placed in cold phosphate-buffered saline (PBS, $10 \mathrm{mM}, \mathrm{pH}$ 7.4). A portion of the cortex and both hippocampus were removed, immediately frozen on dry ice, and stored at $-80{ }^{\circ} \mathrm{C}$.

The tissue samples $(1 \mathrm{~mL} / 100 \mathrm{mg})$ were lysed in cold homogenization buffer containing $0.5 \%$ sodium deoxycholate, $100 \mathrm{mM}$ Tris hydrochloride $(\mathrm{pH}=8.3), 150$ $\mathrm{mM} \mathrm{NaCl}, 10 \mathrm{mM}$ EDTA, 0.1\% SDS, 10\% glycerol, $1 \%$ Triton X-100, and $2 \%$ of a cocktail of protease inhibitors (Sigma-Aldrich; cat. \# P8340) and phosphatase inhibitors (Sigma-Aldrich; cat. \# P0044). Samples were homogenized on ice using disposable tissue-homogenizing tubes (Kimble; cat. \# 749625-0010) and a plastic pestle to disrupt the tissue. Disrupted tissue samples were left on ice and vortexed every $2 \mathrm{~min}$ for $20 \mathrm{~min}$. The supernatant was aliquoted in two $1.5-\mathrm{mL}$ tubes and stored at $-80^{\circ} \mathrm{C}$ for future analysis. Total protein concentration was determined using the Precision Red Advanced protein assay (Cytoskeleton; cat. \# ADV02-A).

\section{Cytokine measurements}

Plasma and tissue homogenates were assayed for the cytokines IL- $1 \beta$ and TNF- $\alpha$ using the DuoSet ELISA kit from $R \& D$ Systems following the manufacturer's instructions (mouse IL-1 $\beta / \mathrm{IL}-1 \mathrm{~F} 2$, cat. \# DY401-05; mouse TNF- $\alpha$, cat. \# DY410-05). Briefly, $50 \mu \mathrm{g}$ of protein was diluted and added to the antibody-containing wells in duplicate for $2 \mathrm{~h}$ at room temperature. Subsequently, the detection antibody-streptavidin-HRP complex was added following the substrate solution containing the color reagents. The absorbance was determined at 450 and $570 \mathrm{~nm}$ using a plate reader (SpectraMax ID3; Molecular Devices). The final absorbance was calculated by subtracting the $570-\mathrm{nm}$ values from the $450-\mathrm{nm}$ values. Standard curves (IL-1 $\beta, 15.6-1000 \mathrm{pg} / \mathrm{ml}$; TNF- $\alpha, 31.2-$ $2000 \mathrm{pg} / \mathrm{ml}$ ) were used to quantify the concentrations of cytokines in $\mathrm{pg} / \mathrm{mL}$. The $\log 10$ of the standard curve values were plotted, and a four-parameter logistic curve was generated to determine the cytokine concentration $(\mathrm{pg} / \mathrm{mL})$ from the measured absorbance.

\section{Novel object recognition test}

The Novel Object Recognition test (NORT) was performed in a black wooden box $(30 \mathrm{~cm} \times 30 \mathrm{~cm} \times 30 \mathrm{~cm})$ with a light (15 lux) in the center of the box following the protocol of Leger et al., 2013 [31]. The test consisted 
of three sessions. Before each session, mice were transported into the behavior-testing facility and were left inside for $30 \mathrm{~min}$. First, there was a 10-min habituation session once a day for 3 days, in which the mice were placed in the empty box to expose them to the testing room and experimental conditions. This was done in order to reduce procedure-related stress, which can affect exploratory behavior. Twenty-four hours later, a familiarization session was carried out. Two identical objects were placed inside the box, and the mice explored both objects freely for $10 \mathrm{~min}$. Exploratory behavior is defined as directing the nose towards the object at a distance of $\leq 2 \mathrm{~cm}$. After the familiarization session, the mice received one of the five treatments described under Sample Collection. The only difference here was the LPS concentration, which was $1 \mathrm{mg} / \mathrm{kg}$ instead of $5 \mathrm{mg} / \mathrm{kg}$. We reduced the concentration of LPS, because mice injected with $5 \mathrm{mg} / \mathrm{kg}$ showed low exploration activity due to sickness behavior. The LPS concentration of 1 $\mathrm{mg} / \mathrm{kg}$ was enough to induce memory deficits in the NORT without altering mouse locomotor activity [14].

The testing session was performed $24 \mathrm{~h}$ post LPS treatment, a time at which the hippocampus has been shown to play a role [32]. Mice were placed in the box with one of the objects used in the familiarization step and with a new object. The time spent exploring was recorded in the familiarization and testing sessions. The box and objects were cleaned with $70 \%$ alcohol before and after each behavioral evaluation to avoid any olfactory cues. Videos were coded and scored by the investigator blinded to the treatments. The percent recognition index was used as a memory parameter using the following formula: $\left[\left(T_{\text {novel }}-T_{\text {familiar }}\right) /\left(T_{\text {novel }}+T_{\text {familiar }}\right)\right] \times 100$, where $T$ represents the length of time exploring the novel object vs. the familiar one. Locomotor activity was also measured during the NORT by recording the total distance traveled (in $\mathrm{cm}$ ) by each mouse. The data collected was analyzed using EthoVision XT V.13 videotracking software (Leesburg, VA).

\section{Signaling protein measurements}

Phosphorylated Akt1 (Ser 473), CREB (Ser 133), and STAT3 (Tyr 705) were analyzed in mouse cortex and hippocampus using a Millipore 96-well magnetic bead multiplex immunoassay (Akt1, cat. \# 48-618MAG; CREB, cat. \# 48-628MAG; STAT3, cat. \# 48-623MAG). Briefly, magnetic beads with fluorescent antibodies against each phosphorylated protein were added to each well. Samples ( $25 \mu \mathrm{g}$ of protein) and positive and negative controls were added in duplicate and left incubating overnight. The detection antibody was added into each well followed by streptavidin-phycoerythrin. The samples were analyzed using the Luminex MAGPIX instrument at 50 events (Luminex Corp). The median fluorescence intensity (MFI) of the phosphorylated form of the protein was divided by its respective amount of total protein for statistical analyses.

\section{Western blot assay}

Wild-type mice were randomly divided into five groups of three. Supernatants ( $25 \mu \mathrm{g}$ of total protein) of hippocampus and cortex from WT mice were mixed with sample buffer containing $\beta$-mercaptoethanol, heated to $95{ }^{\circ} \mathrm{C}$ for $10 \mathrm{~min}$, and resolved in a $10 \%$ SDS-PAGE. The proteins were transferred onto Amersham Hybond ECL nitrocellulose membranes (GE Healthcare Bio-Sciences Corp., Pittsburgh, PA), blocked with 5\% BSA in TBS, and then probed with respective primary antibodies from Cell Signaling Technology (Danvers, MA): Phospho-STAT3 (Tyr 705, 1:1000, Cat. \#: 9145S), Total-STAT3 (1:2000, Cat. \#: 4904S), Phospho-Akt1 (Ser 473, 1:1000, Cat. \#: 9018S), Total-Akt1 (1:1000 Cat. \#:75692S), PhosphoCREB (Ser 133, 1:1000, Cat. \#: 9198S), Total-CREB (1: 1000, Cat. \#: 9197S), and GAPDH (1:1000, Cat. \#: 97166S). The immunoreactive signals were visualized by Odyssey CLx Quantitative Fluorescent Imaging System with fluorescent secondary antibodies: Goat anti-Mouse IRDye 680 RD (1:25,000, Cat. \#: 925-68070) or Goat antiRabbit IRDye 800 CW (1:25,000, Cat. \#: 925-32211). Results were analyzed with Image Studio Lite Software (LICOR Biotechnology, Lincoln, NE). GAPDH immunoreactive signal was used as the loading control.

\section{RNA sequencing analysis}

Both hippocampi from each individual animal were combined and total RNA was extracted from saline-, LPS-, and LPS/4R-treated WT mice and LPS/4R-treated $\alpha 7 \mathrm{KO}$ groups following the protocol of Chomczynski and Sacchi [33]. RNA quantification was measured using a Thermofisher NanoDrop spectrophotometer, (Waltham, MA), and RNA integrity was monitored by loading $2.5 \mu \mathrm{l}$ of each sample into an Agilent 2100 bioanalyzer. One $\mu \mathrm{g}$ of total RNA from each sample was pooled with other samples from the same treatment group into a single tube. The pooled RNA samples were sequenced by the MACROGEN sequencing service using the Illumina next-generation sequencing platform with a HiSeq sequencer and the TruSeq library prep kit. Analysis of the data was conducted using Ingenuity Pathway Analysis (IPA, Qiagen, Germantown, MD) software.

\section{Real-time quantitative PCR analysis}

Hippocampal RNA was isolated using the RNeasy Mini Kit (Qiagen, cat\# 74104) from three mice per treatment. From the total RNA, $0.5 \mu \mathrm{g}$ was used for cDNA synthesis following the $\mathrm{RT}^{2}$ First Strand Kit (Qiagen, cat \# 330401) protocol. RT-qPCR was carried out to determine the mRNA expression using a custom $\mathrm{RT}^{2}$ 
Profiler $^{\mathrm{rm}}$ PCR Array (Qiagen, cat \# CLAM38358). The numbers in parenthesis represent the internal Qiagen gene detection codes for the following genes: orosomucoid 2 (ORM2; PPM04524A), Fos proto-oncogene (FOS; PPM02940C), epithelial cadherin (CDH1; PPM03652F), insulin-like growth factor 2 (IGF2; PPM03655A), coagulation factor XII (F12; PPM28974A), forkhead box A1 (FOXA1; PPM04764H), chemokine ligand 12 (CCL12; PPM02977E), complement component 3 (C3; PPM04471E), thrombospondin 1 (THBS1; PPM03098F), glial cell line-derived neurotrophic factor (GDNF; PPM04315F), calponin 1 (CNN1; PPM05033A), calcium-sensing receptor (CASR; PPM04823A), and glyceraldehyde 3-phosphate dehydrogenase (GAPDH; PPM02946E) as the reference gene.

Quantitative polymerase chain reaction (qPCR) was carried out using the CFX Connect real-time PCR detection system (Bio-Rad, cat. \# 1855200). Each 96-well plate contained two samples run in triplicate. The threshold cycle (CT) value was obtained using CFX Maestro software (Bio-Rad; Hercules, CA), with the same baseline carried over between runs as recommended by the protocol. CT values were analyzed using the $\Delta \Delta C T$ method according to the manufacturer's manual. GAPDH was used as the housekeeping gene for data normalization, and the saline group was used as the control for each $2^{-\Delta \Delta C t}$ calculation. Quality controls used in the array were the reverse transcription control (RTC) and the positive PCR control (PPC).

\section{Statistical analysis}

The data were analyzed by one-way or two-way analysis of variance (ANOVA), followed by Tukey's multiple comparisons test, unless otherwise specified. The assumption of homogeneity of variances was verified using the Brown-Forsythe test for equality of group variances. When the variance between groups was not homogeneous, a nonparametric ANOVA followed by Dunn's post hoc test was used. When comparing two experimental groups, a two-sample $t$-test was performed. Results are presented as mean \pm S.E.M. and were analyzed using GraphPad Prism v8.4 software (Bellevue, WA). $P$ values $<0.05$ were considered statistically significant.

\section{Results}

4R-cembranoid neuroprotection against NMDA in mouse hippocampal slices

Figure 1 shows the structure of $4 \mathrm{R}$, which consists of a 14-carbon cembrane ring substituted with two hydroxy groups, attached to carbons 4 and 6 , and three methyl groups. The hydrophobic ring and an electronegative atom at carbon 4 with R-chirality are known to be important for their neuroprotective activity [34]. To determine whether the neuroprotection previously reported in rats can be seen in mice, we prepared mouse

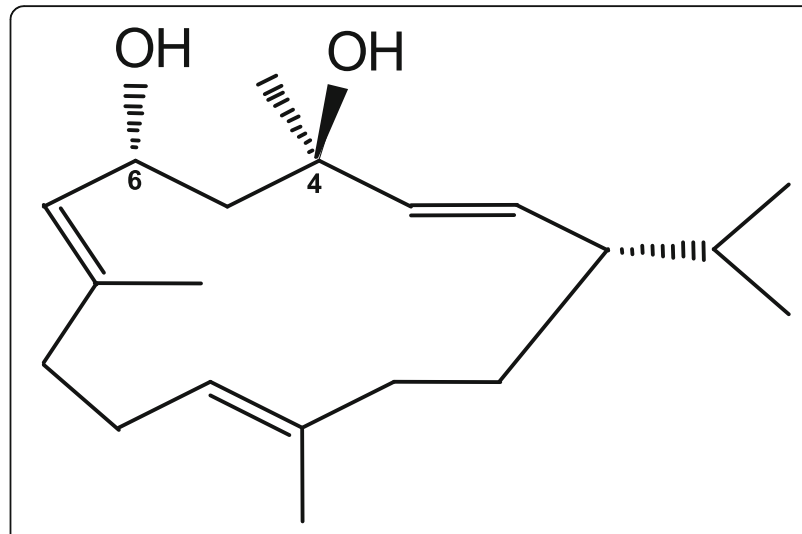

Fig. 1 Structural formula of $4 R$

hippocampal slices using a similar protocol [20] (Fig. 2a). As an example, a graphical representation of the percent population spike recovery for one experiment is shown in Fig. 2b. Figure 2c shows that $10 \mu \mathrm{M}$ 4R applied after NMDA significantly increases the percent population spike (PS) recovery in both WT and $\alpha 7 \mathrm{KO}$ mice. Wild-type mice recovered $62 \%$, whereas $\alpha 7 \mathrm{KO}$ mice recovered 70\% of the NMDA-induced PS loss. The $\alpha 7$ and $\alpha 4 \beta 2$ receptors are the most abundant nicotinic acetylcholine receptors in the brain hippocampus [35]. Hippocampal slices from $\alpha 7 \mathrm{KO}$ mice were treated with $1 \mu \mathrm{M}$ $\mathrm{DH} \beta \mathrm{E}$, and at this concentration, $\mathrm{DH} \beta \mathrm{E}$ selectively inhibits $\alpha 4 \beta 2$ neuronal receptors [36]. After incubation with $4 \mathrm{R}$ in the absence or presence of $\mathrm{DH} \beta \mathrm{E}$, the PS following NMDA toxicity significantly recovered (by $80 \%$ and $73 \%$, respectively, Fig. 2d). No significant differences were observed between the slices treated with $4 R$ and those treated with $4 \mathrm{R}$ and $\mathrm{DH} \beta \mathrm{E}$. To test whether $4 \mathrm{R}$ neuroprotection in hippocampal slices is mediated by the $\alpha 7$ receptor, $10 \mathrm{nM}$ MLA was added to WT slices treated with NMDA + 4R (Fig. 2e). MLA at $10 \mathrm{nM}$ selectively inhibits $\alpha 7$ acetylcholine receptors [36]. In the presence of MLA, the percent PS recovery was less than, but not significantly different from, the percent PS recovery without MLA ( $49 \%$ versus $62 \%, p=0.09, t$-test not shown). The percent PS recovery in WT slices treated with DH $\beta E$ was also similar (69\%, Fig. 2e) to the percent PS recovery without DH $\beta E$ (62\%, Fig. 2c, $p=$ $0.62, t$-test not shown). These results corroborate the neuroprotective role of $4 \mathrm{R}$ against NMDA neurotoxicity in mice, and point to a mechanism that is independent of the $\alpha 7$ and $\alpha 4 \beta 2$ nicotinic acetylcholine receptor pathways.

\section{Plasma and brain TNF- $\alpha$ and IL-1 $\beta$ levels}

We examined TNF- $\alpha$ and IL- $1 \beta$ concentrations in plasma, hippocampus, and cerebral cortex in both WT and $\alpha 7 \mathrm{KO}$ mice $24 \mathrm{~h}$ after LPS stimulation. As expected, TNF- $\alpha$ and IL-1 $\beta$ levels were significantly elevated in 


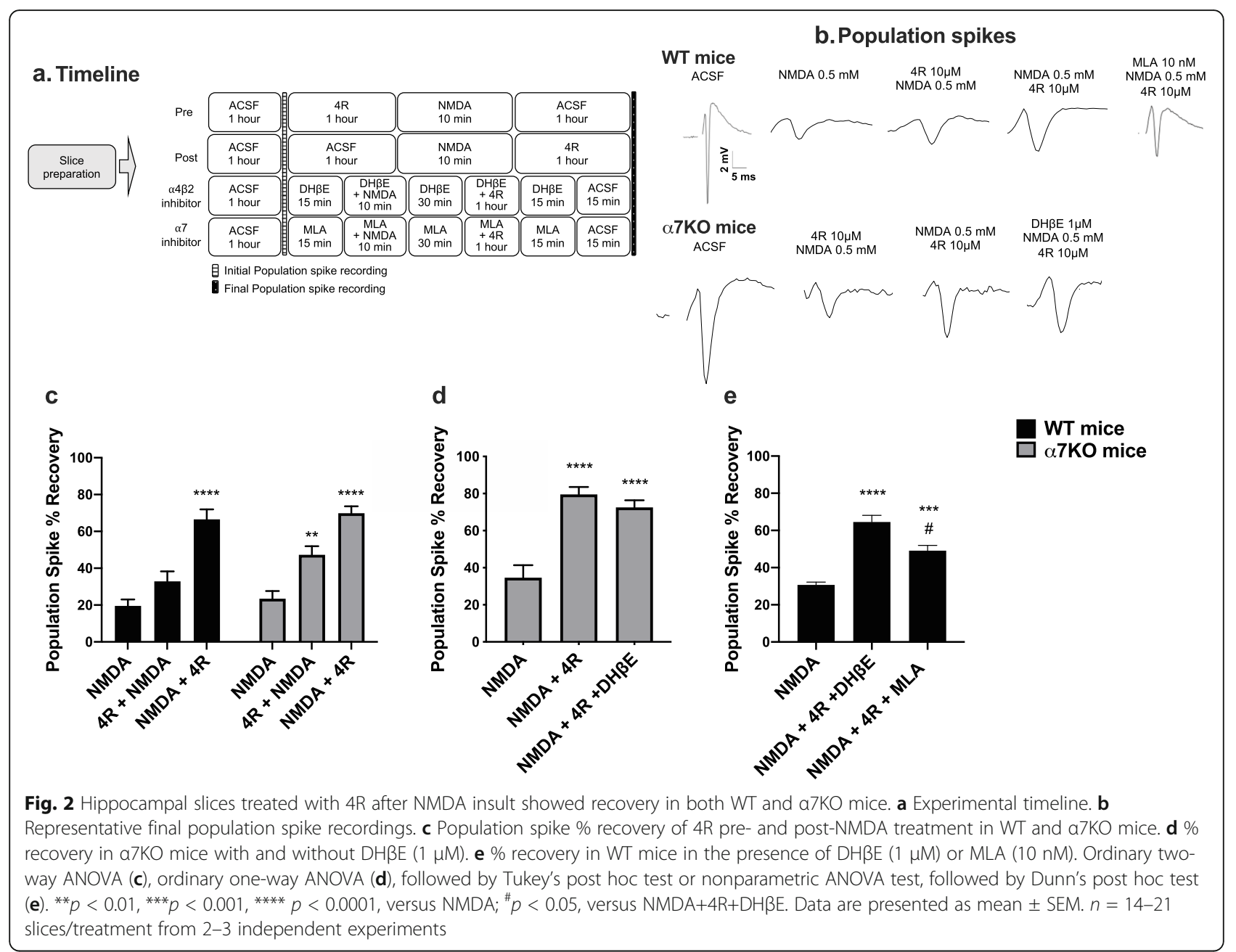

plasma, hippocampus, and cortex in the LPS/saline (sal)treated mice compared with saline control in both WT and $\alpha 7 \mathrm{KO}$ mice (Fig. 3). The LPS/veh-treated mice WT hippocampus IL- $1 \beta$ group mean tended to be lower than the LPS/sal group mean, but did not reach statistical significance. 4R alone (without LPS) had no effect on TNF$\alpha$ and IL- $1 \beta$ levels in any of the areas examined and behaved like the saline control. To investigate the antiinflammatory effect of 4R, 2 h after LPS administration $(5 \mathrm{mg} / \mathrm{kg})$ the mice were treated with $4 \mathrm{R}(6 \mathrm{mg} / \mathrm{kg})$ or vehicle for $22 \mathrm{~h}$. Plasma and hippocampal cytokine levels were significantly reduced in the WT LPS/4R groups compared with the LPS/sal group. A similar 4R effect was demonstrated in the $\alpha 7 \mathrm{KO}$ mouse hippocampus. Moreover, in $\alpha 7 \mathrm{KO}$ mice, $4 \mathrm{R}$ treatment lowered IL- $1 \beta$ levels in plasma and TNF- $\alpha$ levels in the cortex compared with the LPS/sal group. No 4R effect was noted in the WT mouse cortex. There was a treatment-genotype interaction in the plasma of LPS/sal and LPS/vehicle (veh) groups, as TNF- $\alpha$ levels in $\alpha 7 \mathrm{KO}$ mice were lower than in WT. This was a surprise, since the anti- inflammatory vagus nerve activity in $\alpha 7 \mathrm{KO}$ mice was not present. A genotype-treatment interaction was also observed in the cortex, as significantly higher TNF- $\alpha$ levels were noted in LPS/sal $\alpha 7 \mathrm{KO}$ versus WT mice. These data indicate that $4 \mathrm{R}$ treatment reduces the levels of TNF- $\alpha$ and IL- $1 \beta$ in plasma and hippocampus of WT and $\alpha 7 \mathrm{KO}$ mice. In the cortex, a lowering effect is observed in the TNF- $\alpha$ levels of $\alpha 7 \mathrm{KO}$ mice.

\section{The 4R-cembranoid effect on long-term memory deficits} is associated with LPS-induced neuroinflammation

Next, we investigated the role of $4 \mathrm{R}$ on long-term memory function after an LPS challenge of $1 \mathrm{mg} / \mathrm{kg}$ in both WT and $\alpha 7 \mathrm{KO}$ mice (Fig. 4). 4R alone had no effect on the novel object recognition index (RI) and performed similarly to the saline control group in both WT and $\alpha 7 \mathrm{KO}$ mice. Analysis of the time mice spent exploring the objects during the familiarization phase showed no significant difference between treatment groups and genotypes. LPS-treated WT and $\alpha 7 \mathrm{KO}$ mice had no exploratory preference for the novel object. LPS/sal-treated 


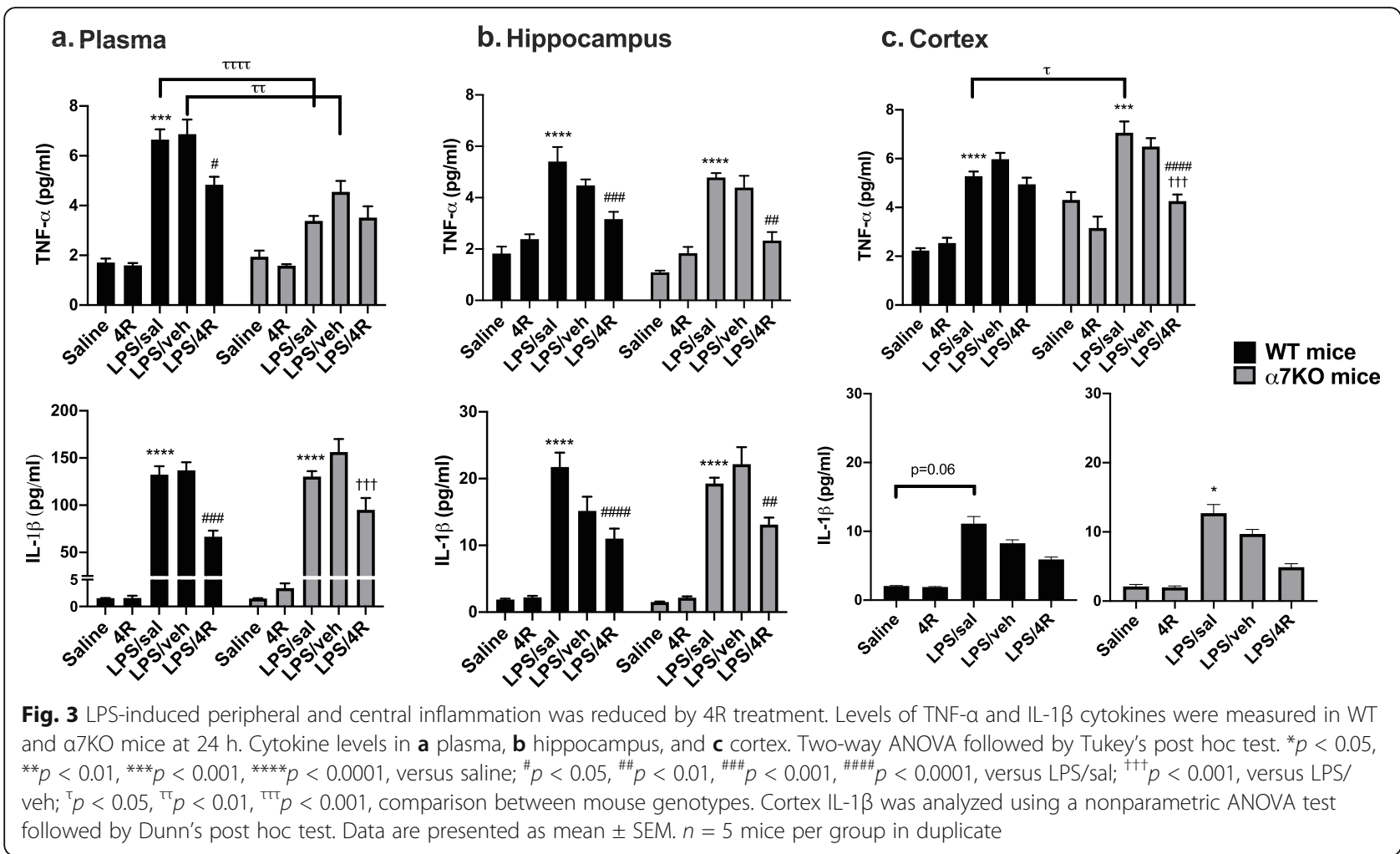

WT and $\alpha 7 \mathrm{KO}$ groups had significantly lower RI than the saline controls. Interestingly, there was a tendency in the LPS/sal-treated $\alpha 7 \mathrm{KO}$ mice to perform better than the LPS/sal-treated WT mice $(p=0.05)$. This suggests an adaptational change that affects the behavioral function in the $\alpha 7 \mathrm{KO}$ mice when exposed to an insult. The loss of the $\alpha 7$ gene could potentially be compensated by increased transcription of other genes important for memory, such as the $\alpha 4$ and $\beta 2$ genes. Both the $\alpha 7$ and the $\alpha 4 \beta 2$ nicotinic acetylcholine receptors have been shown to be important for hippocampal-dependent memory function [37]. On the other hand, Freund and colleagues demonstrated the importance of genetic background on hippocampal synaptic plasticity [38]. The authors showed that the hippocampal long-term potentiation in the $\alpha 7 \mathrm{KO}$ C57/Bl6 mice was normal, but it was impaired in $\alpha 7 \mathrm{KO}$ mice maintained in the $\mathrm{C} 3 \mathrm{H}$ background. No genotype effect in NORT performance was observed in the saline- or 4R-only-treated groups. $4 \mathrm{R}$ administration significantly increased the percent RI in both WT $(\mathrm{RI}=27 \%)$ and $\alpha 7 \mathrm{KO}(\mathrm{RI}=32 \%)$ mice to baseline levels (WT, $\mathrm{RI}=28 \% ; \alpha 7 \mathrm{KO}, \mathrm{RI}=22 \%$ ). $4 \mathrm{R}$ rescued the memory impairments induced by LPS through a mechanism independent of the $\alpha 7$ acetylcholine

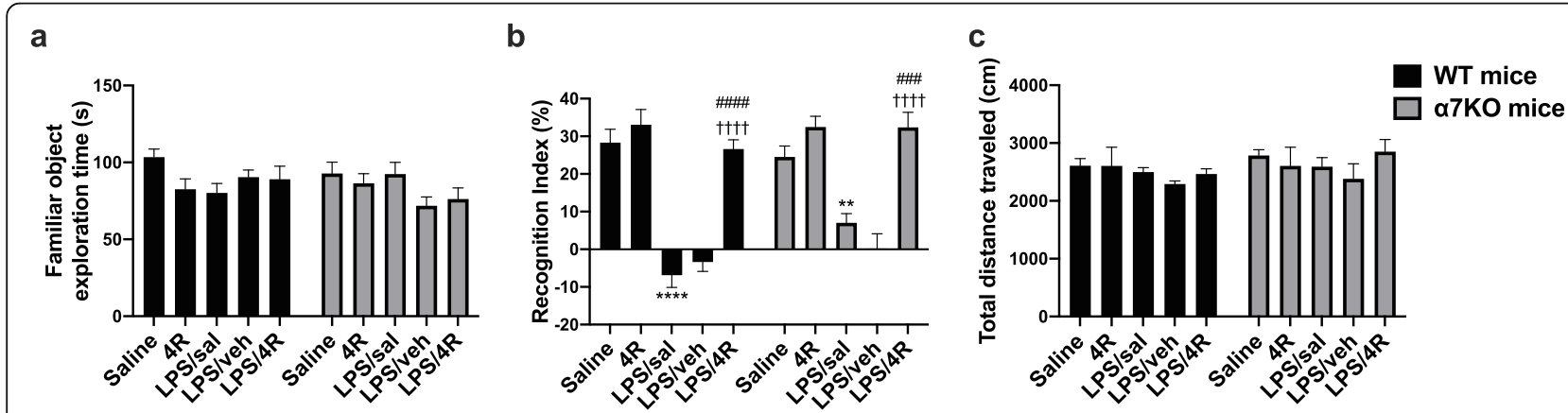

Fig. 4 LPS-induced memory deficits were mitigated by 4R. a Exploration time during the familiarization step. b Recognition index \% for WT and a7KO mice. c Locomotor activity was measured by the total distance traveled during NORT. Two-way ANOVA followed by Tukey's post hoc test. ${ }^{* *} p<0.01,{ }^{* * *} p<0.0001$, versus saline; ${ }^{\# \# \#} p<0.001$, ${ }^{\# \# \#} p<0.0001$, versus LPS/sal; ${ }^{+++t} p<0.0001$, versus LPS/veh. Data are presented as mean \pm SEM. $n=5-9$ mice per group 
receptor. Neither treatment nor genotype altered the locomotor activity measured by the distance traveled in an open field during NORT. These data show that the detrimental effects of LPS on memory function were corrected by $4 \mathrm{R}$ treatment.

\section{STAT3, Akt1, and CREB phosphorylation in cortex and hippocampus}

Total and phosphorylated amounts were measured in the hippocampus and cortex of WT and $\alpha 7 \mathrm{KO}$ mice at $24 \mathrm{~h}$ under our experimental conditions (Fig. 5). We did not observe a significant LPS effect on the phosphorylation of these proteins, only a trend to increase pCREB when compared with saline control in WT mice cortex. Others have reported a significant reduction in PCREB $24 \mathrm{~h}$ after an LPS dose of $3 \mathrm{mg} / \mathrm{kg}$ i.p. in mouse hippocampus [39] and an increase in pSTAT3 $24 \mathrm{~h}$ after an intracerebroventricular LPS injection [40]. In our hands, 4R treatment significantly increased Akt1, STAT3, and CREB phosphorylation in WT mouse hippocampus compared with LPS/sal- or LPS/veh-treated groups (Fig. 5a-c). 4R treatment did not affect WT cortex STAT3, Akt1, or CREB phosphorylation (Fig. 5d-f). The only significant effect of $4 \mathrm{R}$ in $\alpha 7 \mathrm{KO}$ cortex was an increase in Akt1 phosphorylation when compared with LPS/salor LPS/veh-treated groups. A genotype-treatment interaction was noted between the WT and $\alpha 7 \mathrm{KO}$ LPS/4Rtreated groups (Fig. 5e). A chronic absence of the $\alpha 7$ receptor eliminated the phosphorylation of STAT3 and CREB in both hippocampus and cortex, regardless of treatment. $\alpha 7$ receptor-mediated anti-inflammatory activity involves activation of JAK2-STAT3 signaling [41]. It is possible that the shutdown of the vagal efferent nerve activity in $\alpha 7 \mathrm{KO}$ mice suppressed STAT3 signaling. Impaired IL-6-STAT3 signaling in $\alpha 7 \mathrm{KO}$ mouse liver was also reported by Kimura and colleagues [42]. Activation of $\alpha 7$ receptors induces CREB phosphorylation by increasing intracellular $\mathrm{Ca}^{2+}$ and cAMP levels [43-45]. However, these are not the only intracellular signals that can increase CREB phosphorylation, and this may, in part, explain the lack of pCREB in $\alpha 7 \mathrm{KO}$ mice.

Western blot analysis of STAT3, Akt, and CREB phosphorylation in WT mice showed similar results to those obtained with the multiplex immunoassay. We included a $4 \mathrm{R}$ only-treated group to see if $4 \mathrm{R}$ alone could have an effect on protein phosphorylation. LPS/4R-treated mice hippocampus had a significantly higher STAT-3 and CREB phosphorylation when compared with LPS/sal and/or LPS/veh-treated groups (Fig. 5h, j). Akt1 phosphorylation was lower in the LPS/veh group as compared with saline control. Both $4 \mathrm{R}$ alone and LPS/4R treatments increased Akt1 phosphorylation when compared with LPS/sal and LPS/veh groups (Fig. 5i). This implies a $4 \mathrm{R}$ effect on Akt1 phosphorylation under both normal and pro-inflammatory conditions. As observed with the immunoassay, the phosphorylation of Akt1 and CREB in the WT cortex was not statistically significant (Fig. $5 \mathrm{~m}-\mathrm{n}$ ). The STAT3 phosphorylation was significantly higher in the LPS/sal group as compared with saline and 4R alone. There was an increase of phosphorylation of STAT3 as compared with LPS/veh effect in LPS/4R-treated mice cortex, but this increase did not reach statistical significance $(p=0.06)$ (Fig.5l). These findings suggest that $4 \mathrm{R}$ treatment following an LPS insult activates the CREB and STAT3 signaling pathways, and that $4 \mathrm{R}$ activates Akt1 with or without an LPS insult in the WT mice hippocampus.

\section{RNA sequencing analysis}

We performed RNA sequencing analysis for saline-, LPS-, and LPS/4R-treatment groups in the WT mouse hippocampus and in the LPS/4R-treatment group for $\alpha 7 \mathrm{KO}$ mouse hippocampus. The mRNA signals obtained were analyzed and segmented into clusters using IPA software. Twelve mRNAs (see list in the "Methods" section) involved in neuroinflammation, neuronal death, and microglia activation with the highest fold change ( $\mathrm{FC}=2$-fold upregulation or 0.5 downregulation) were selected and validated by RT-qPCR (Supplemental Table 1). Of the $12 \mathrm{mRNAs}$ analyzed, 5 were significantly upregulated by $4 R$ treatment (Fig. 6). The other 7 genes are presented in Supplemental Fig. 1aS. ORM2 mRNA expression was the only mRNA significantly downregulated by LPS $(\mathrm{FC}=0.59)$ compared with saline. For each of the 5 genes, we calculated the 4R-induced fold change by dividing the mean mRNA expression in the LPS/4Rtreatment group by the mean mRNA expression in the LPS-treatment group. 4R treatment significantly increased the mRNA levels of ORM2 $(\mathrm{FC}=2.9)$, GDNF $(\mathrm{FC}=1.9)$, and $\mathrm{C} 3(\mathrm{FC}=5.9)$ compared with LPS treatment (Fig. 6a). The mRNA levels in $\alpha 7 \mathrm{KO}$ mice were not statistically different from WT (data shown in supplemental Fig. 1bS), except for the expression of ORM2. The $\alpha 7 \mathrm{KO}$ mice had significantly lower ORM2 mRNA levels than WT (Fig. 6b). There was a weak 4R effect on the mRNA levels of THBS1 ( $\mathrm{FC}=1.9 ; p=0.06)$ and CNN1 ( $\mathrm{FC}=1.5 ; p=0.07$ ) versus LPS. The RT-PCR data indicate that $4 \mathrm{R}$ increased the mRNA levels of ORM2, GDNF, and C3, and modestly increased the mRNA levels of THBS1 and CNN1 $24 \mathrm{~h}$ after LPS exposure.

\section{Discussion}

The ability of $4 \mathrm{R}$ to elicit neuronal survival was demonstrated in rat hippocampal slices using different neurotoxic agents, which showed that the neuroprotective effect of $4 R$ was significant at concentrations of $0.2-40$ $\mu \mathrm{M}$ and that $4 \mathrm{R}$ alone does not affect the NMDA 


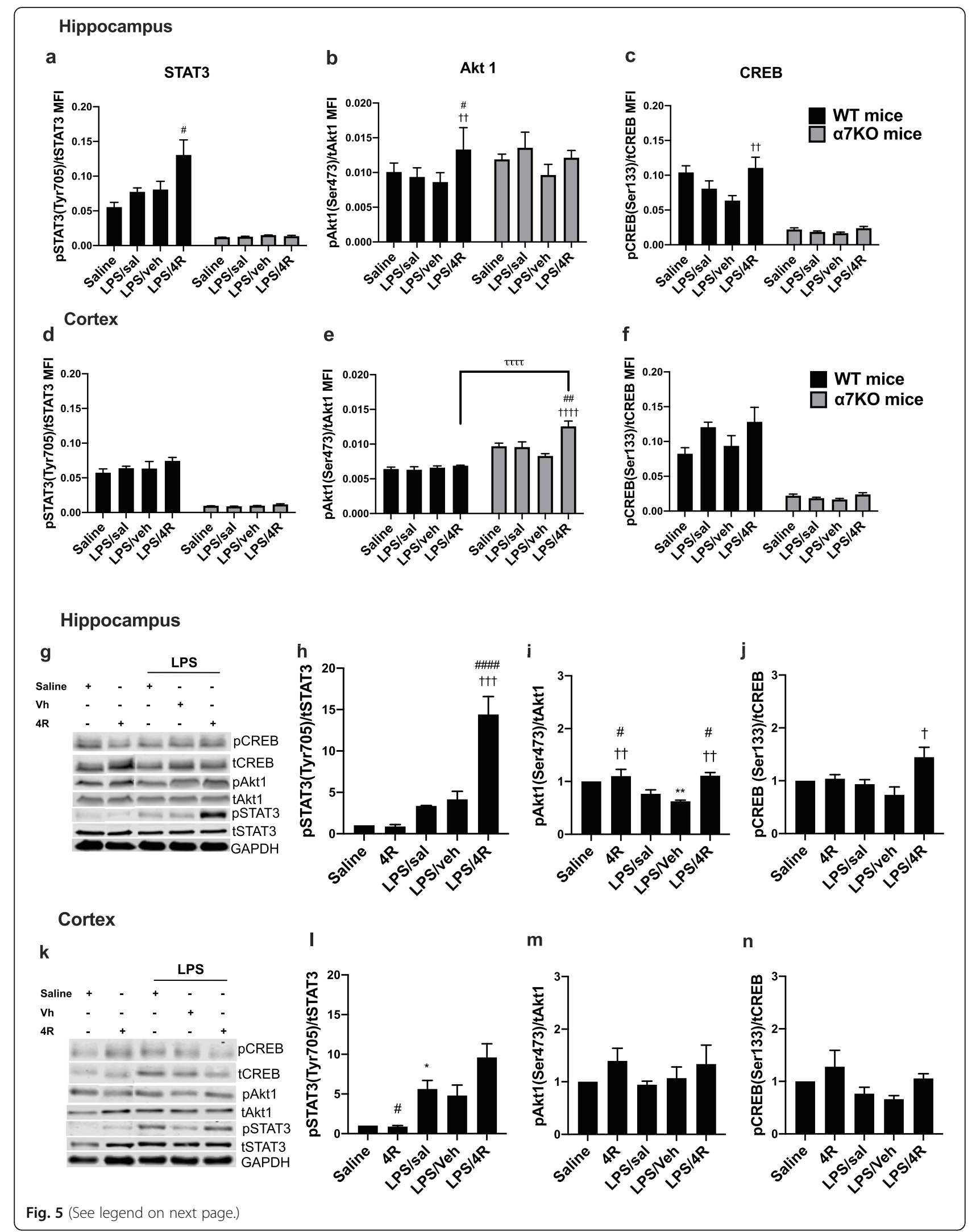


(See figure on previous page.)

Fig. 5 Effect of 4R on STAT3, Akt1, and CREB phosphorylation in WT and a7KO mice. Each graph represents the phosphorylated form normalized by total protein. a-c Hippocampus median fluorescence intensity (MFI) in both WT and a7KO mice. $\mathbf{d}-\mathbf{f}$ Cortex MFI in both mouse strains. $\mathbf{a}$, $\mathbf{d}$ pSTAT3 at Tyr 705. b, e pAkt1 at Ser 473. c, f pCREB at Ser 133. g-n Protein expression of pSTAT3, pAkt1, and pCREB in WT mice analyzed by Western blot in the hippocampus $(\mathbf{g}-\mathbf{j})$, and cortex $(\mathbf{k}-\mathbf{n})$ at the same phosphorylation sites. a-f Two-way ANOVA followed by Tukey's post hoc

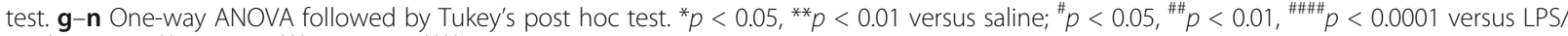
$\mathrm{sal}^{{ }^{+}} p<0.05,{ }^{+\dagger} p<0.01,{ }^{++t} p<0.001,{ }^{+t+t} p<0.0001$, versus LPS/veh; ${ }^{\pi t T} p<0.0001$, LPS/4R WT versus LPS/4R a7KO mice. Data presented as mean \pm SEM. $n=5$ mice per group in duplicate, for Western blot $n=3$ per group

receptor-mediated population spike (PS). 4R did not protect by blocking NMDA receptors but by activating the PI3K-Akt1 anti-apoptotic signaling pathway [2022].

Our first aim was to confirm the neuroprotective effect of $4 \mathrm{R}$ in mouse hippocampal slices treated with NMDA. We demonstrated that $4 \mathrm{R}$ application after NMDA exposure significantly recovers the loss of neuronal population spikes (PS) in hippocampal slices of both WT and $\alpha 7 \mathrm{KO}$ mice (Fig. 2). Although neuroprotection was also observed when $4 \mathrm{R}$ was applied before NMDA, it was more robust when applied after NMDA exposure. Coincubation of $4 \mathrm{R}$ with $\mathrm{DH} \beta \mathrm{E}$ after NMDA did not interfere with the neuroprotective action of $4 \mathrm{R}$ in WT or $\alpha 7 \mathrm{KO}$ mice, which implies that the $\alpha 4 \beta 2$ acetylcholine receptors are not involved in the neuroprotective mechanism of $4 R$. Co-incubation of $4 R$ with MLA after NMDA in WT hippocampal slices recovered the neuronal PS. Taken together our results show that the $\alpha 4 \beta 2$ and $\alpha 7$ nicotinic receptors are not involved in the $4 \mathrm{R}$ mediated PS recovery when administered after NMDA in mice.

The main goal of our study was to investigate the neuroprotective role of $4 \mathrm{R}$ during CNS inflammation and the mechanisms for this effect. $4 \mathrm{R}$ treatment decreased TNF- $\alpha$ and IL- $1 \beta$ levels in WT and $\alpha 7 \mathrm{KO}$ mouse hippocampus. Mice treated with $4 \mathrm{R}$ completely recovered from the memory deficits associated with LPS stimulation (Fig. 4). This was observed in both genotypes, demonstrating an $\alpha 7$-independent mechanism. Some of the detrimental effects of LPS on memory function have been attributed to IL- $1 \beta$ and TNF$\alpha$ production. Li et al have reported that inhibition of IL-1 $\beta$ production in the dentate gyrus of the hippocampus improves cognitive function in mice [46]. IL$1 \beta$-silenced mice treated with LPS had a NORT recognition index similar to mice treated with saline. Using a different hippocampal-dependent learning test, Belardi and colleagues demonstrated that reduction of TNF- $\alpha$ mRNA levels in the hippocampus resulted in a significant improvement in the Morris water maze task in rats [47].

Next, we determined the effect of $4 R$ on the phosphorylation status of STAT3, Akt1, and CREB. 4R treatment significantly increased the phosphorylation of Akt1, CREB, and STAT3 in the hippocampus of WT mice and Akt1 phosphorylation in the cortex of $\alpha 7 \mathrm{KO}$ mice (Fig. 5). The PI3K-Akt1 signaling pathway is well recognized as one of the most important pathways modulating cell survival [48, 49]. We confirmed previous in vitro reports of Akt1 activation by 4R [23, 24]. Using an in vitro model of Parkinson's a. WT mice

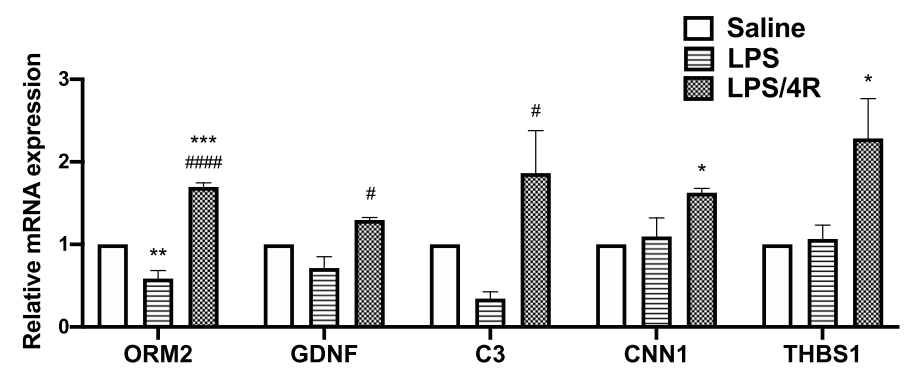

b. Genotype effect

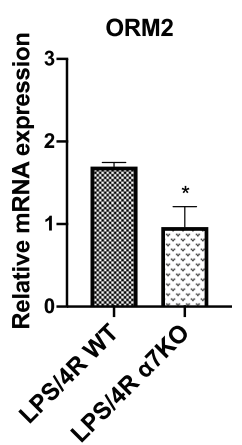

Fig. 6 Hippocampal relative mRNA expression in WT mice $24 \mathrm{~h}$ after LPS exposure. a Relative mRNA expression of C3, THBS1, GDNF, CNN1, and ORM2 in WT mice. $\mathbf{b}$ ORM2 relative mRNA expression comparing WT and a7KO mice. Ordinary one-way ANOVA followed by Tukey post hoc test. ${ }^{*} p<0.05,{ }^{* *} p<0.01,{ }^{* * *} p<0.001$, versus saline; ${ }^{\#} p<0.05$, ${ }^{\# \#} p<0.01$, ${ }^{\# \# \# ~} p<0.05$, versus LPS. b t-test between WT and a7KO mice. ${ }^{*} p<0.05$, versus LPS/4R WT. Data presented as mean \pm SEM. $n=3$ mice per group in triplicate 
disease, $\mathrm{Hu}$ and colleagues showed an increase in pAkt with $4 \mathrm{R}$ in a dose-dependent manner [24]. Martins and coworkers also reported an increase in pAkt in neuronal cells under normal conditions and during oxygen-glucose deprivation conditions [23]. In our study, we showed an increase in pAkt1 with $4 \mathrm{R}$ alone and with LPS/4R. Thus, 4R could protect hippocampal neurons against pro-apoptotic signals by increasing Akt phosphorylation in the absence or presence of an insult. Although full Akt1 activation requires phosphorylation of the S473 and T308 residues, phosphorylation of S473 stabilizes T308 phosphorylation and the active state of Akt1 [49].CREB activation stimulates neuronal survival and hippocampal longterm memory [44]. Activation of the $\alpha 7$ receptor increases CREB phosphorylation through $\mathrm{Ca}^{2+}$ entry and PKA phosphorylation [45], but our results show that the loss of this receptor abolishes CREB signaling.

STAT3 phosphorylation was significantly enhanced by $4 \mathrm{R}$ in the hippocampus of WT mice, although the role of STAT3 activation in inflammation and neuronal survival is less clear. It can induce pro- or antiinflammatory responses, depending on the activation pathway (IL-6 or IL-10, respectively). Increased pSTAT3 in human neural progenitor cells treated with IL-1 $\beta$ and TNF- $\alpha$ to mimic brain inflammation showed inhibition of neuronal differentiation and stimulation of astrocyte differentiation, but the opposite effect of inhibition of astrocyte differentiation and stimulation of neuronal differentiation was observed when STAT3 signaling was silenced [50].

Gene expression analysis showed a significant upregulation of Orosomucoid 2 (ORM2), GDNF, and C3 mRNA levels with $4 \mathrm{R}$ versus LPS treatment. ORM2 protein is found in astrocytes, and it plays a role in controlling microglia activation during inflammation and neuronal survival [51]. Myungjin and collaborators showed that intracerebroventricular injection of ORM2 reduces neuroinflammation and microglial activation in the hippocampus and cortex $24 \mathrm{~h}$ after LPS stimulation [51]. ORM2 treatment partially reversed the hippocampal-dependent spatial memory deficits induced by LPS. The $\alpha 7$ acetylcholine receptor is involved in ORM2 expression, since our results showed lowered expression in $\alpha 7 \mathrm{KO}$ versus WT mice. GDNF is secreted by astrocytes and has been shown to inhibit microglial activation in vitro [18]. Recent work demonstrated that GDNF and its receptor, GFR $\alpha 1$, are important for the maturation of adultborn dentate gyrus hippocampal neurons and spatial memory formation [52]. They also reported an increase in CREB phosphorylation in dentate gyrus-derived neuronal cells treated with GDNF but not in
GFR $\alpha 1$ mutant cells, indicating a role for GDNF and GFR $\alpha 1$ in activating CREB. On the other hand, Mitroshina and coworkers reported a neuroprotective role for GDNF through Akt activation in mouse primary hippocampal neurons exposed to hypoxic conditions [53]. C3 factor is part of the complement system found in microglia and astrocytes. C3a is a peptide generated by factor $\mathrm{C} 3$ cleavage during complement activation. Co-stimulation of rat primary culture astrocytes with $\mathrm{C} 3 \mathrm{a}$ and IL-1 $\beta$ increased nerve growth factor (NGF) protein expression [54]. C3a also protected mouse primary cortical astrocytes from chemical-induced ischemia by inhibiting caspase 3 cleavage and ERK phosphorylation [55].

Thrombospondin1 (THBS1) (also known as TSP-1) and CNN1 mRNA levels were modestly increased by $4 \mathrm{R}$ versus LPS treatment. CNN1 is a protein found in the mouse hippocampus that is important for vascular smooth muscle regulation [56]. THBS1 is an extracellular protein secreted by astrocytes that is important for vascular remodeling. THBS1-knockout mice displayed higher BBB disruption, neuronal death, and hippocampal-dependent learning impairments after traumatic brain injury [57]. Although our results need protein validation, they suggest that $4 \mathrm{R}$ may modulate astrocyte function to protect the hippocampus during inflammation.

Previous studies supported a direct neuroprotective effect of $4 R$ in the brain, and $4 R$ has been shown to decrease the infarct size in a rat transient ischemic stroke model [23] and to improve motor function in a rat model of Parkinson's disease [24]. We have previously shown that intravenous injection of $4 \mathrm{R}$ reaches the brain within $10 \mathrm{~min}$ and that the $4 \mathrm{R}$ concentration in the brain was six times that in plasma [25]. When $4 \mathrm{R}$ was administered subcutaneously, its concentration in the brain was twice that in plasma due to a lower bioavailability. Our results demonstrate a $4 \mathrm{R}$ effect that is not mediated by $\alpha 7$ receptors as beneficial effects of $4 R$ were unaffected in the $\alpha 7 \mathrm{KO}$ mice. In summary, 4R-cembranoid has a potential neuroprotective value during pathological conditions where adverse immune responses and cognitive impairments are present such as in neurodegenerative diseases, brain injury, chronic stress, and aging $[1,10,58]$.

\section{Conclusion}

$4 \mathrm{R}$ protects the hippocampus against inflammation and memory impairments triggered by LPS by lowering TNF$\alpha$ and IL-1 $\beta$ levels and activation of the Akt1 and CREB signaling pathways. Astrocyte proteins involved in neuronal survival also seem to be modulated by $4 R$. The effects of $4 R$ in the hippocampus are independent of $\alpha 7$ nicotinic receptors. The diagram below represents a model of $4 R$ action in the hippocampus during inflammation. 


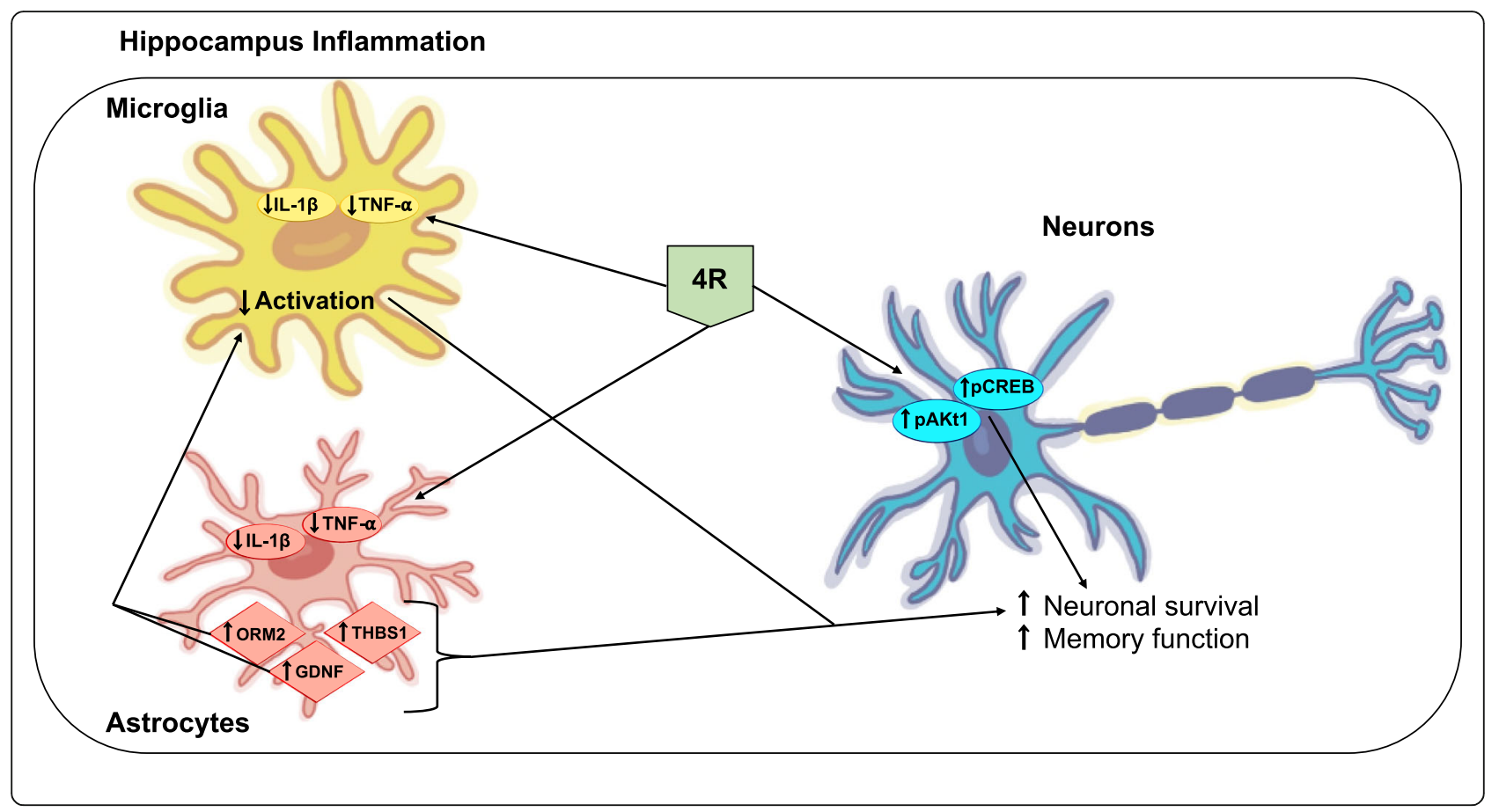

\section{Abbreviations}

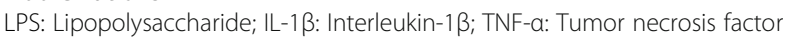
alpha; MCP-1: Monocyte chemoattractant protein 1; IL-6: Interleukin 6; NFkb: Nuclear factor kappa-light-chain-enhancer of activated B cells; PEG: Polyethylane glycol; DMSO: Dimethyl sulfoxide; NMDA: N-Methyl-Daspartate; DHßE: Dihydro-b-erythroidine; MLA: Methyllycaconitine; PS: Population spike; Akt1: Serine-threonine protein kinase 1; CREB: CAMP response element-binding protein; STAT3: Signal transducer and activator of transcription 3; ORM2: Orosomucoid 2; C3: Complement component 3:

THBS1: Thrombospondin 1; GDNF: Glial cell line-derived neurotrophic factor; CNN1: Calponin 1

\section{Supplementary Information}

The online version contains supplementary material available at https://doi. org/10.1186/s12974-021-02136-9.

Additional file 1.

Additional file 2 .

\section{Acknowledgements}

The authors are grateful to Dinely Perez for performing the hippocampal slice experiments.

\section{Authors' contributions}

WVT, LRC, and PKD were the main researchers that participated in the design and implementation of the study. LRC, FMV, and MLD performed in vivo and molecular experiments. GMM performed the statistical analyses. PAF handed the $4 \mathrm{R}$ used for this study and helped us with the design of the ex vivo hippocampal slice experiments. JBR assisted with the RNA sequencing and gene analysis. WVT and LRC participated in writing the manuscript. All authors read and approved the final manuscript.

\section{Funding}

This work was supported by the following grants: NIH (SC3), no. SC3GM130473; RISE, no. R25GM110513; and SNR, no. U54NS083924.

\section{Availability of data and materials}

The data sets generated and/or analyzed during the current study are available from the corresponding author on reasonable request.

\section{Declarations}

Ethics approval and consent to participate

All animal experiments were performed in accordance with the Institutional Animal Care and Use Committee at UCC (IACUC \#021-2016-13-01-PHA). Consent to participate for human subjects was not applicable in this study.

Consent for publication

Not applicable

\section{Competing interests}

The authors declare that they have no competing interests.

\section{Author details}

${ }^{1}$ Department of Biochemistry, Universidad Central del Caribe School of Medicine, Av. Sta. Juanita, Bayamón 00960, Puerto Rico. ²Department of Neurobiology and Anatomy, McGovern Medical School, University of Texas Health Science Center at Houston, Houston, TX 77030, USA. ${ }^{3}$ University of Puerto Rico Molecular Science Research Center, Av. Juan Ponce de León, San Juan 00926, Puerto Rico.

Received: 5 December 2020 Accepted: 22 March 2021

Published online: 19 April 2021

\section{References}

1. Guerriero F, Sgarlata C, Francis M, Maurizi N, Faragli A, Perna S, et al. Neuroinflammation, immune system and Alzheimer disease: searching for the missing link. Aging Clin Exp Res. 2017;29(5):821-31. https://doi.org/10.1 007/s40520-016-0637-z.

2. Gelders G, Baekelandt V, Van der Perren A. Linking Neuroinflammation and neurodegeneration in Parkinson's disease. J Immunol Res. 2018;2018: 4784268.

3. Brites D, Fernandes A. Neuroinflammation and Depression: microglia activation, extracellular microvesicles and microRNA dysregulation. Front Cell Neurosci. 2015;9:476.

4. Ziebell JM, Morganti-Kossmann MC. Involvement of pro- and antiinflammatory cytokines and chemokines in the pathophysiology of 
traumatic brain injury. Neurotherapeutics. 2010;7(1):22-30. https://doi.org/1 0.1016/..nurt.2009.10.016

5. Copeland S, Warren HS, Lowry SF, Calvano SE, Remick D, Inflammation, the Host Response to Injury I. Acute inflammatory response to endotoxin in mice and humans. Clin Diagn Lab Immunol. 2005;12(1):60-7. https://doi. org/10.1128/CDLI.12.1.60-67.2005.

6. Juskewitch JE, Knudsen BE, Platt JL, Nath KA, Knutson KL, Brunn GJ, et al. LPS-induced murine systemic inflammation is driven by parenchymal cell activation and exclusively predicted by early MCP-1 plasma levels. Am J Pathol. 2012;180(1):32-40. https://doi.org/10.1016/j.ajpath.2011.10.001.

7. Trotta T, Porro C, Calvello R, Panaro MA. Biological role of Toll-like receptor-4 in the brain. J Neuroimmunol. 2014;268(1-2):1-12. https://doi.org/10.1016/j. jneuroim.2014.01.014.

8. Pavlov VA, Tracey KJ. The vagus nerve and the inflammatory reflex-linking immunity and metabolism. Nat Rev Endocrinol. 2012;8(12):743-54. https:// doi.org/10.1038/nrendo.2012.189.

9. Skelly DT, Hennessy E, Dansereau MA, Cunningham C. A systematic analysis of the peripheral and CNS effects of systemic LPS, IL-1 beta, [corrected] TNFalpha and IL-6 challenges in C57BL/6 mice. PLoS One. 2013;8(7):e69123. https://doi.org/10.1371/journal.pone.0069123.

10. Qin L, Wu X, Block ML, Liu Y, Breese GR, Hong JS, et al. Systemic LPS causes chronic neuroinflammation and progressive neurodegeneration. Glia. 2007; 55(5):453-62. https://doi.org/10.1002/glia.20467.

11. Cazareth J, Guyon A, Heurteaux C, Chabry J, Petit-Paitel A. Molecular and cellular neuroinflammatory status of mouse brain after systemic lipopolysaccharide challenge: importance of CCR2/CCL2 signaling. J Neuroinflammation. 2014;11(1):132. https://doi.org/10.1186/1742-2 094-11-132.

12. Erickson MA, Banks WA. Cytokine and chemokine responses in serum and brain after single and repeated injections of lipopolysaccharide: multiplex quantification with path analysis. Brain Behav Immun. 2011;25(8):1637-48. https://doi.org/10.1016/j.bbi.2011.06.006.

13. Vasconcelos AR, Yshii LM, Viel TA, Buck HS, Mattson MP, Scavone C, et al. Intermittent fasting attenuates lipopolysaccharide-induced neuroinflammation and memory impairment. J Neuroinflammation. 2014; 11(1):85. https://doi.org/10.1186/1742-2094-11-85.

14. Fruhauf PK, Ineu RP, Tomazi L, Duarte T, Mello CF, Rubin MA. Spermine reverses lipopolysaccharide-induced memory deficit in mice. J Neuroinflammation. 2015;12(1):3. https://doi.org/10.1186/s12974-014-0220-5.

15. Neumann H, Kotter MR, Franklin RJ. Debris clearance by microglia: an essential link between degeneration and regeneration. Brain. 2009;132(Pt 2): 288-95. https://doi.org/10.1093/brain/awn109.

16. Ryu KY, Lee HJ, Woo H, Kang RJ, Han KM, Park H, et al. Dasatinib regulates LPS-induced microglial and astrocytic neuroinflammatory responses by inhibiting AKT/STAT3 signaling. J Neuroinflammation. 2019;16(1):190. https://doi.org/10.1186/s12974-019-1561-x.

17. Tang Y, Le W. Differential Roles of M1 and M2 Microglia in Neurodegenerative Diseases. Mol Neurobiol. 2016;53(2):1181-94. https://doi. org/10.1007/s12035-014-9070-5.

18. Rocha SM, Cristovao AC, Campos FL, Fonseca CP, Baltazar G. Astrocytederived GDNF is a potent inhibitor of microglial activation. Neurobiol Dis. 2012;47(3):407-15. https://doi.org/10.1016/.j.nbd.2012.04.014

19. Yan N, Du Y, Liu X, Zhang H, Liu Y, Zhang Z. A Review on Bioactivities of Tobacco Cembranoid Diterpenes. Biomolecules. 2019;9(1). https://doi.org/1 0.3390/biom9010030.

20. Ferchmin PA, Hao J, Perez D, Penzo M, Maldonado HM, Gonzalez MT, et al. Tobacco cembranoids protect the function of acute hippocampal slices against NMDA by a mechanism mediated by alpha4beta2 nicotinic receptors. J Neurosci Res. 2005;82(5):631-41. https://doi.org/10.1002/jnr.20666.

21. Eterovic VA, Perez D, Martins AH, Cuadrado BL, Carrasco M, Ferchmin PA. A cembranoid protects acute hippocampal slices against paraoxon neurotoxicity. Toxicol In Vitro. 2011;25(7):1468-74. https://doi.org/10.1016/j. tiv.2011.04.021.

22. Ferchmin PA, Andino M, Reyes Salaman R, Alves J, Velez-Roman J, Cuadrado $B$, et al. 4R-cembranoid protects against diisopropylfluorophosphatemediated neurodegeneration. Neurotoxicology. 2014;44:80-90. https://doi. org/10.1016/j.neuro.2014.06.001

23. Martins $\mathrm{AH}, \mathrm{Hu} J, \mathrm{Xu} Z \mathrm{Z}, \mathrm{Mu} \mathrm{C}$, Alvarez $\mathrm{P}$, Ford BD, et al. Neuroprotective activity of (1S,2E,4R,6R,-7E,11E)-2,7,11-cembratriene-4,6-diol (4R) in vitro and in vivo in rodent models of brain ischemia. Neuroscience. 2015;291:250-9. https://doi.org/10.1016/j.neuroscience.2015.02.001.
24. Hu J, Ferchmin PA, Hemmerle AM, Seroogy KB, Eterovic VA, Hao J. 4Rcembranoid improves outcomes after 6-hydroxydopamine challenge in both in vitro and in vivo models of Parkinson's disease. Front Neurosci. 2017:11:272. https://doi.org/10.3389/fnins.2017.00272.

25. Velez-Carrasco W, Green CE, Catz P, Furimsky A, O'Loughlin K, Eterovic VA, et al. Pharmacokinetics and Metabolism of 4R-Cembranoid. PLoS One. 2015; 10(3):e0121540. https://doi.org/10.1371/journal.pone.0121540.

26. Tyagi E, Agrawal R, Nath C, Shukla R. Inhibitory role of cholinergic system mediated via alpha7 nicotinic acetylcholine receptor in LPS-induced neuroinflammation. Innate Immun. 2010;16(1):3-13. https://doi.org/10.1177/1 753425909104680.

27. Dash PK, Zhao J, Kobori N, Redell JB, Hylin MJ, Hood KN, et al. Activation of alpha 7 cholinergic nicotinic receptors reduce blood-brain barrier permeability following experimental traumatic brain injury. J Neurosci. 2016; 36(9):2809-18. https://doi.org/10.1523/JNEUROSCI.3197-15.2016.

28. Ferchmin PA, Lukas RJ, Hann RM, Fryer JD, Eaton JB, Pagan OR, et al. Tobacco cembranoids block behavioral sensitization to nicotine and inhibit neuronal acetylcholine receptor function. J Neurosci Res. 2001;64(1):18-25. https://doi.org/10.1002/jnr.1049

29. Ferchmin PA, Perez D, Castro Alvarez W, Penzo MA, Maldonado HM, Eterovic VA. gamma-Aminobutyric acid type A receptor inhibition triggers a nicotinic neuroprotective mechanism. J Neurosci Res. 2013;91(3):416-25. https://doi.org/10.1002/jnr.23155.

30. El Sayed KA, Laphookhieo S, Baraka HN, Yousaf M, Hebert A, Bagaley D, et al. Biocatalytic and semisynthetic optimization of the anti-invasive tobacco (1S,2E,4R,6R,7E,11E)-2,7,11-cembratriene-4,6-diol. Bioorg Med Chem. 2008;16(6):2886-93. https://doi.org/10.1016/j.bmc.2007.12.056.

31. Leger M, Quiedeville A, Bouet V, Haelewyn B, Boulouard M, Schumann-Bard P, et al. Object recognition test in mice. Nat Protoc. 2013;8(12):2531-7. https://doi.org/10.1038/nprot.2013.155.

32. Hammond RS, Tull LE, Stackman RW. On the delay-dependent involvement of the hippocampus in object recognition memory. Neurobiol Learn Mem. 2004;82(1):26-34. https://doi.org/10.1016/j.nlm.2004.03.005.

33. Chomczynski P, Mackey K. Substitution of chloroform by bromochloropropane in the single-step method of RNA isolation. Anal Biochem. 1995:225(1):163-4. https://doi.org/10.1006/abio.1995.1126.

34. Eterovic VA, Del Valle-Rodriguez A, Perez D, Carrasco M, Khanfar MA, El Sayed KA, et al. Protective activity of (1S,2E,4R,6R,7E,11E)-2,7,11cembratriene-4,6-diol analogues against diisopropylfluorophosphate neurotoxicity: preliminary structure-activity relationship and pharmacophore modeling. Bioorg Med Chem. 2013;21(15):4678-86. https://doi.org/10.1016/j. bmc.2013.05.018.

35. Haam J, Yakel JL. Cholinergic modulation of the hippocampal region and memory function. J Neurochem. 2017;142(Suppl 2):111-21. https://doi.org/1 $0.1111 /$ jnc. 14052

36. Raggenbass M, Bertrand D. Nicotinic receptors in circuit excitability and epilepsy. J Neurobiol. 2002;53(4):580-9. https://doi.org/10.1002/neu.10152.

37. Kenney JW, Gould TJ. Modulation of hippocampus-dependent learning and synaptic plasticity by nicotine. Mol Neurobiol. 2008;38(1):101-21. https://doi. org/10.1007/s12035-008-8037-9.

38. Freund RK, Graw S, Choo KS, Stevens KE, Leonard S, Dell'Acqua ML. Genetic knockout of the alpha7 nicotinic acetylcholine receptor gene alters hippocampal long-term potentiation in a background strain-dependent manner. Neurosci Lett. 2016;627:1-6. https:/doi.org/10.1016/j.neulet.2016.05.043.

39. Zong MM, Yuan HM, He X, Zhou ZQ, Qiu XD, Yang JJ, et al. Disruption of Striatal-enriched protein tyrosine phosphatase signaling might contribute to memory impairment in a mouse model of sepsis-associated encephalopathy. Neurochem Res. 2019;44(12):2832-42. https://doi.org/10.1 007/s11064-019-02905-2.

40. Hosoi T, Okuma Y, Kawagishi T, Qi X, Matsuda T, Nomura Y. Bacterial endotoxin induces STAT3 activation in the mouse brain. Brain Res. 2004; 1023(1):48-53. https://doi.org/10.1016/j.brainres.2004.06.076.

41. de Jonge WJ, Ulloa L. The alpha7 nicotinic acetylcholine receptor as a pharmacological target for inflammation. Br J Pharmacol. 2007;151(7):91529. https://doi.org/10.1038/sj.bjp.0707264.

42. Kimura K, Tanida M, Nagata N, Inaba Y, Watanabe H, Nagashimada M, et al. Central insulin action activates Kupffer cells by suppressing hepatic vagal activation via the nicotinic alpha 7 acetylcholine receptor. Cell Rep. 2016; 14(10):2362-74. https://doi.org/10.1016/j.celrep.2016.02.032.

43. Cheng $\mathrm{Q}$ Yakel $\mathrm{J}$. Activation of alpha7 nicotinic acetylcholine receptors increases intracellular CAMP levels via activation of AC1 in hippocampal 
neurons. Neuropharmacology. 2015;95:405-14. https://doi.org/10.1016/j. neuropharm.2015.04.016.

44. Ortega-Martinez S. A new perspective on the role of the CREB family of transcription factors in memory consolidation via adult hippocampal neurogenesis. Front Mol Neurosci. 2015;8:46.

45. Kalkman HO, Feuerbach D. Modulatory effects of alpha7 nAChRs on the immune system and its relevance for CNS disorders. Cell Mol Life Sci. 2016; 73(13):2511-30. https://doi.org/10.1007/s00018-016-2175-4.

46. Li M, Li C, Yu H, Cai X, Shen X, Sun X, et al. Lentivirus-mediated interleukin1 beta (IL-1 beta) knock-down in the hippocampus alleviates lipopolysaccharide (LPS)-induced memory deficits and anxiety- and depression-like behaviors in mice. J Neuroinflammation. 2017;14(1):190. https://doi.org/10.1186/s12974-017-0964-9.

47. Belarbi K, Jopson T, Tweedie D, Arellano C, Luo W, Greig NH, et al. TNFalpha protein synthesis inhibitor restores neuronal function and reverses cognitive deficits induced by chronic neuroinflammation. J Neuroinflammation. 2012;9:23.

48. Song $G$, Ouyang $G$, Bao $S$. The activation of Akt/PKB signaling pathway and cell survival. J Cell Mol Med. 2005;9(1):59-71. https://doi.org/10.1111/j.1582-4 934.2005.tb00337.x.

49. Manning BD, Toker A. AKT/PKB Signaling: navigating the Network. Cell. 2017;169(3):381-405. https://doi.org/10.1016/j.cell.2017.04.001.

50. Chen E, Xu D, Lan X, Jia B, Sun L, Zheng JC, et al. A novel role of the STAT3 pathway in brain inflammation-induced human neural progenitor cell differentiation. Curr Mol Med. 2013;13(9):1474-84. https://doi.org/10.2174/1 5665240113139990076

51. Jo M, Kim JH, Song GJ, Seo M, Hwang EM, Suk K. Astrocytic orosomucoid-2 modulates microglial activation and neuroinflammation. J Neurosci. 2017; 37(11):2878-94. https://doi.org/10.1523/JNEUROSCI.2534-16.2017.

52. Bonafina A, Trinchero MF, Rios AS, Bekinschtein P, Schinder AF, Paratcha $G$ et al. GDNF and GFRalpha1 are required for proper integration of adult-born hippocampal neurons. Cell Rep. 2019;29(13):4308-19 e4304. https://doi. org/10.1016/j.celrep.2019.11.100.

53. Mitroshina capital le C, Mishchenko TA, Shirokova OM, Astrakhanova TA, Loginova MM, Epifanova EA, et al. Intracellular neuroprotective mechanisms in neuron-glial networks mediated by glial cell line-derived neurotrophic factor. Oxid Med Cell Longev. 2019:2019:1036907.

54. Jauneau AC, Ischenko A, Chatagner A, Benard M, Chan P, Schouft MT, et al. Interleukin-1 beta and anaphylatoxins exert a synergistic effect on NGF expression by astrocytes. J Neuroinflammation. 2006;3(1):8. https://doi.org/1 0.1186/1742-2094-3-8.

55. Shinjyo N, de Pablo Y, Pekny M, Pekna M. Complement peptide C3a promotes astrocyte survival in response to ischemic stress. Mol Neurobiol. 2016:53(5):3076-87. https://doi.org/10.1007/s12035-015-9204-4.

56. Stankiewicz AM, Goscik J, Majewska A, Swiergiel AH, Juszczak GR. The effect of acute and chronic social stress on the hippocampal transcriptome in mice. PLoS One. 2015;10(11):e0142195. https://doi.org/10.1371/journal.pone. 0142195.

57. Cheng C, Yu Z, Zhao S, Liao Z, Xing C, Jiang Y, et al. Thrombospondin-1 gene deficiency worsens the neurological outcomes of traumatic brain injury in mice. Int J Med Sci. 2017;14(10):927-36. https://doi.org/10.7150/ ijms.18812.

58. DiSabato DJ, Quan N, Godbout JP. Neuroinflammation: the devil is in the details. J Neurochem. 2016;139(Suppl 2):136-53. https://doi.org/10.1111/ jnc.13607.

\section{Publisher's Note}

Springer Nature remains neutral with regard to jurisdictional claims in published maps and institutional affiliations.

Ready to submit your research? Choose BMC and benefit from:

- fast, convenient online submission

- thorough peer review by experienced researchers in your field

- rapid publication on acceptance

- support for research data, including large and complex data types

- gold Open Access which fosters wider collaboration and increased citations

- maximum visibility for your research: over $100 \mathrm{M}$ website views per year

At $\mathrm{BMC}$, research is always in progress.

Learn more biomedcentral.com/submissions 